\title{
Amino acids in interstitial waters from ODP Sites 689 and 690 on the Maud Rise, Antarctic Ocean
}

\author{
HODAKA KAWAHATA ${ }^{1,2}$ and TOSHIO ISHIZUKA ${ }^{3}$ \\ ${ }^{1}$ Marine Geology Department, Geological Survey of Japan, 1-3 Higashi-1, Tsukuba 305-8567, Japan \\ ${ }^{2}$ Graduate School of Science, Tohoku University, Aoba, Sendai 980-8578, Japan \\ ${ }^{3}$ Ocean Research Institute, University of Tokyo, 1-15 Minamidai-1 Nakano-ku, Tokyo 164-8639, Japan
}

(Received July 8, 1999; Accepted February 1, 2000)

\begin{abstract}
Biogenic calcareous and siliceous sediments were drilled at ODP Sites 689 and 690 on the Maud Rise, Antarctic Ocean. We analyzed dissolved combined amino acids (DCAA) and dissolved free amino acids (DFAA) in interstitial waters in order to characterize the amino acids in dissolved organic matter. The DFAA was predominant over the DCAA in interstitial waters at Sites 689 and 690, which contradicted the previous results from interstitial water and seawater studies. The DCAA in the interstitial waters probably originated from calcareous biogenic debris with less amounts of siliceous debris. Although glutamic acid constituted $41 \%$ of the total concentration of DCAA, it accounted for only $1 \%$ of the total concentration of DFAA due to the adsorption and/or reaction with biogenic carbonate. Ornithine, a nonprotein amino acid, is a decomposed product of arginine and made up $17 \mathrm{~mol} \%$ of the total DFAA and. The total hydrolyzable amino acids (=DCAA + DFAA) accounted for 5 to $28 \%$ of the dissolved organic carbon (DOC) concentration, which implied that high molecular weight organic matter was a major contributor for the DOM (dissolved organic matter) in interstitial waters. Fairly positive correlation between the dissolved manganese and the total DCAA values suggested that the redox condition plays a significant role in controlling the total DCAA content. A small decrease in the sulfate concentration in the interstitial waters from both sites suggested fairly low microbial activity by sulfate-reducing bacteria.
\end{abstract}

\section{INTRODUCTION}

Dissolved organic matter (DOM) in seawater and interstitial waters is one of the largest, but least understood, active reservoirs of organic carbon on the earth (Hedges, 1988). DOM freshly produced by plankton is labile and rapidly oxidized by heterotrophic organisms (Azam et al., 1983). However, the mean age of DOM in seawater is more than 4,000 yr (Bauer et al., 1992), indicating that a large portion of the DOM pool consists of refractory compounds. At the moment, $20-30 \%$ of the DOM pool can be characterized at a molecular level (Williams and Druffel, 1987).

Amino acids are common in all organisms and are major nitrogenous compounds in sinking particles, sediments and interstitial waters (e.g.,
Henrichs and Farrington, 1979; Ittekkot et al., 1984a, b; Haake et al., 1992). However, amino acids in the sediments usually decompose more rapidly than total sediment organic carbon (e.g., Whelan, 1977; Maita et al., 1982; Henrichs et al., 1984). Especially dissolved free amino acids (DFAA) are utilized by microorganisms within a day or less (Christensen and Blackburn, 1980; Fuhrman, 1990), making it unlikely that DFAA persist long enough to undergo abiotic reaction. In contrast, dissolved combined amino acids (DCAA) may be more important in the formation of refractory DOM. Collins et al. (1991, 1992) identified proteins and hydrolyzable amino acids in fossilized marine organisms, indicating that proteins can persist for long periods of time under certain conditions. 
Difference in concentrations and compositions of DCAA and DFAA in interstitial waters may reflect the differing time scale of supply and removal: tens of years or more for organic carbon and amino acids in the sediments, but much less for DFAA (Henrichs and Farrington, 1979; Jørgensen et al., 1981; Henrichs et al., 1984; Christensen and Blackburn, 1980). Because the amino acid concentrations in interstitial waters are much less than those in sediments, even small changes in the latter would lead to large changes in the former. Thus, DCAA and DFAA in interstitial waters seem to be sensitive and important indicators of early diagenesis. So far, little work on this subject, particularly on DCAA in interstitial waters, has been carried out in deep sedimentary holes (e.g., Ishizuka et al., 1988; Kawahata and Ishizuka, 1989, 1992, 1993; Kawahata et al., 1990). This paper presents the results of the DCAA and DFAA in interstitial waters collected at Sites 689 and 690 during Ocean Drilling Program (ODP) Leg 113, and discusses the characteristics of DCAA and DFAA and the relationship between the DCAA, DFAA and dissolved organic carbon (DOC) in interstitial waters.

\section{MATERIALS AND METHODS}

\section{Sampling and storage}

Interstitial waters from the sediments at ODP Sites 689 and 690 were collected aboard JOIDES Resolution by hydraulic squeezing. All interstitial water samples were filtered through $0.22 \mu \mathrm{m}$ Millipore cellulose acetate filters in the shipboard laboratory. For amino acid analysis of the interstitial water, a $5 \mathrm{~mL}$ aliquot of the water sample was placed in a precombusted glass ampoule. After being flushed with helium, the ampoule was sealed and stored refrigerated $\left(1-2^{\circ} \mathrm{C}\right)$ until delivery to the land-based laboratory.

\section{Analytical procedures: Amino acids}

The DFAA in the interstitial waters were analyzed after the addition of $7 \mu \mathrm{L}$ ultrapure (amino acid-free) $6 \mathrm{M} \mathrm{HCl}$ to $0.7 \mathrm{~mL}$ of an interstitial water sample. Amino acid concentrations were determined by direct injection of the sample into an automated liquid chromatograph (Hitachi model 835). The reported concentrations were corrected for the reagent blank.

For total hydrolyzable amino acids (THAA), $1 \mathrm{~mL}$ of interstitial water, together with $1 \mathrm{~mL}$ of ultrapure $12 \mathrm{M} \mathrm{HCl}$ to adjust the solution to $6 \mathrm{M}$ $\mathrm{HCl}$, was placed in a precombusted glass ampoule and hydrolyzed at $110^{\circ} \mathrm{C}$ for $22 \mathrm{hr}$ under argon atmosphere. Then, the solution was evaporated gently using a rotary evaporator at a temperature lower than $42^{\circ} \mathrm{C}$ and the residue was redissolved in $1 \mathrm{~mL}$ of $0.01 \mathrm{M} \mathrm{HCl}$. This aliquot was injected into the amino acid analyzer. The standard deviation for amino acid analysis based on replicate measurements of a standard solution (about $1 \mu \mathrm{mol}$ $\mathrm{L}^{-1}$ for amino acids) was $<10 \%$, and the detection

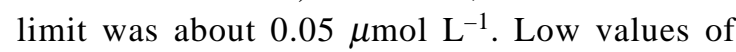
DFAA and THAA near the detection limit may not be dependable. The concentration of the DCAA can be calculated by subtracting the DFAA concentration from the THAA concentration in the interstitial waters.

\section{SumMary OF THE GeOlogical FrameWORK}

Site 689 is situated at $64^{\circ} 31.01^{\prime} \mathrm{S}, 3^{\circ} 06.00^{\prime} \mathrm{E}$ near the crest of the Maud Rise at a water depth of 2,080 m (Fig. 1). Sediment samples for interstitial waters were taken from cores collected from Hole 689B drilled to $297.3 \mathrm{~m}$ below seafloor (mbsf). The recovered sediments were pelagic, biogenic in origin, and ranged in age from Campanian/Maestrichtian to Pleistocene. The sequence was divided into three lithostratigraphic units based upon compositional differences and diagenetic maturity (Egeberg et al., 1990).

Unit 1 (0-31.0 mbsf; late Miocene to Pleistocene) consisted predominantly of diatom ooze with varying amounts of other biosiliceous components.

Unit 2 (2A: 31.0-72.1 mbsf; 2B: 72.1-149.1 mbsf; late Eocene to late Miocene) consisted of a mixture of biosiliceous and calcareous oozes. The calcareous component (mainly nannofossils) increased downward. 


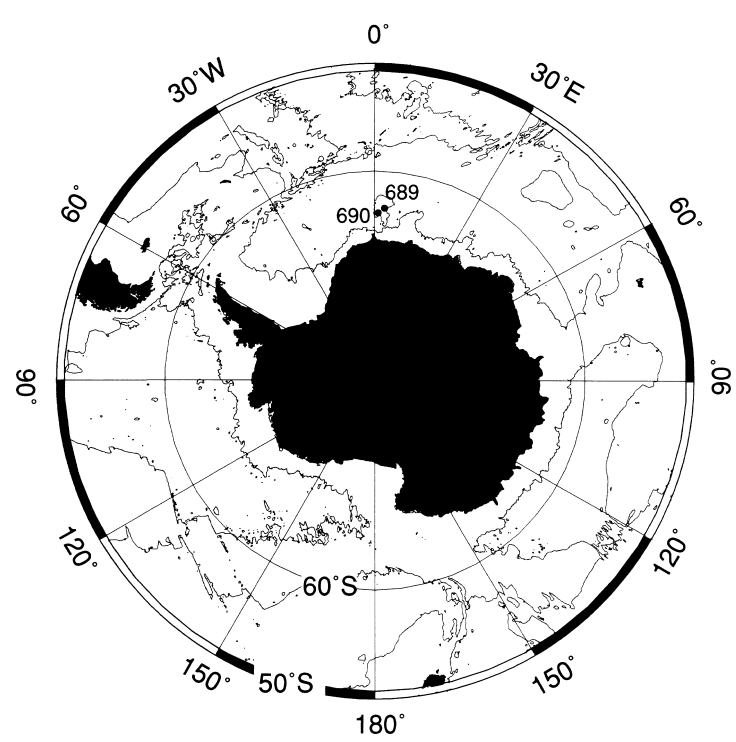

Fig. 1. Location map showing positions of ODP Sites 689 and 690 on the Maud Rise, Antarctic Ocean.

Unit 3 (149.1-297.3 mbsf; Campanian to late Eocene) consisted of nannofossil ooze and chalk.

Zeolite, chert and altered volcanic ash-bearing layers were minor components (Barker et al., 1988). The clay size fraction was dominated by smectite and illite down to $110 \mathrm{mbsf}$ and by smectite below 110 mbsf. Carbonate content was very low (0-3.9 wt.\%) in Unit 1, variable in Unit 2A (0.8-91.3 wt.\%) and high in Units $2 \mathrm{~B}$ and 3 (75.5-98.1 wt.\%). Organic carbon content was low throughout the hole with the mean value $0.11 \mathrm{wt} . \%$ (Egeberg and Abdullah, 1990).

Site 690 was located at $65^{\circ} 9.63^{\prime} \mathrm{S}, 1^{\circ} 12.30^{\prime} \mathrm{E}$ on the southwest flank of the Maud Rise at a water depth of 2,914 m (Fig. 1). Sediment samples were taken from cores collected from Holes 690A, $\mathrm{B}$ and $\mathrm{C}$ drilled to $321.2 \mathrm{mbsf}$. The sediments ranged in age from late Cretaceous to Pleistocene. The sequence was mainly biogenic, but terrigenous and volcanic detritus became significant components around $140 \mathrm{mbsf}$. Samples for interstitial water were collected from depth down to 264.5 mbsf. The clay size fraction was dominated by smectite except in the upper 90 mbsf where illite was equally abundant to or more common (Barker et al., 1988).
Unit $1(0-24.4 \mathrm{mbsf}$; late Miocene to Pleistocene) consisted of $2.1 \mathrm{~m}$ of foraminiferal ooze overlying diatom ooze with varying amounts of other biosiliceous components.

Unit 2 (2A: 24.4-53.4 mbsf; 2B: 53.4-92.9 mbsf; early Oligocene to late Miocene) consisted of pure and mixed biogenic siliceous and calcareous oozes.

Unit 3 (92.9-137.8 mbsf; late Paleocene to early Oligocene) consisted of foraminiferal oozes.

Unit 4 (137.8-281.1 mbsf; late Maestrichtian to late Paleocene) consisted of nannofossil oozes and chalk with a terrigenous component of 10 $15 \%$.

Carbonate content was very low (0-0.8 wt.\%) in Unit 1 except for the surface, and high in Units 2 and 3 except for the middle of Unit 2A. Organic carbon content was also low, averaging $0.15 \mathrm{wt} . \%$ (Egeberg and Abdullah, 1990).

\section{INORGANIC CHEMISTRY OF THE INTERSTITIAL WATERS}

The chlorinity and $\mathrm{pH}$ were about $558 \mu \mathrm{mol}$ $\mathrm{L}^{-1}$ and 7.63, respectively, and were fairly constant throughout the hole drilled at Site 689. The sulfate concentration decreased gradually from 29.5 to $26.32 \mathrm{mmol} \mathrm{L}^{-1}$ at the bottom (Fig. 2), which suggested fairly low activity of sulfate-reducing bacteria. The profile of alkalinity was similar to that of sulfate. The alkalinity decreased from 3.19 to $2.06 \mathrm{mmol} \mathrm{L}^{-1}$. However, the calcium concentration increased with depth from 11.4 to 20.9 mmol L $\mathrm{L}^{-1}$. The manganese concentration had a broad maximum between 75 and 125 mbsf (Fig. 2). It was, however, an order of magnitude lower than that in the pelagic sites in the Antarctic Ocean (Barker et al., 1988).

The chlorinity and $\mathrm{pH}$ with the mean values of $549 \mathrm{mmol} \mathrm{L}^{-1}$ and 7.78 , respectively, were fairly constant throughout the holes of Site 690. The sulfate concentration decreased with increasing depth from 29.2 to $21.0 \mathrm{mmol} \mathrm{L}^{-1}$ (Fig. 3). The calcium concentration increased from 10.8 to 16.1 mmol L ${ }^{-1}$. The alkalinity increased with depth from 2.84 to $4.04 \mathrm{mmol} \mathrm{L}^{-1}$ in the upper $143.5 \mathrm{~m}$ 


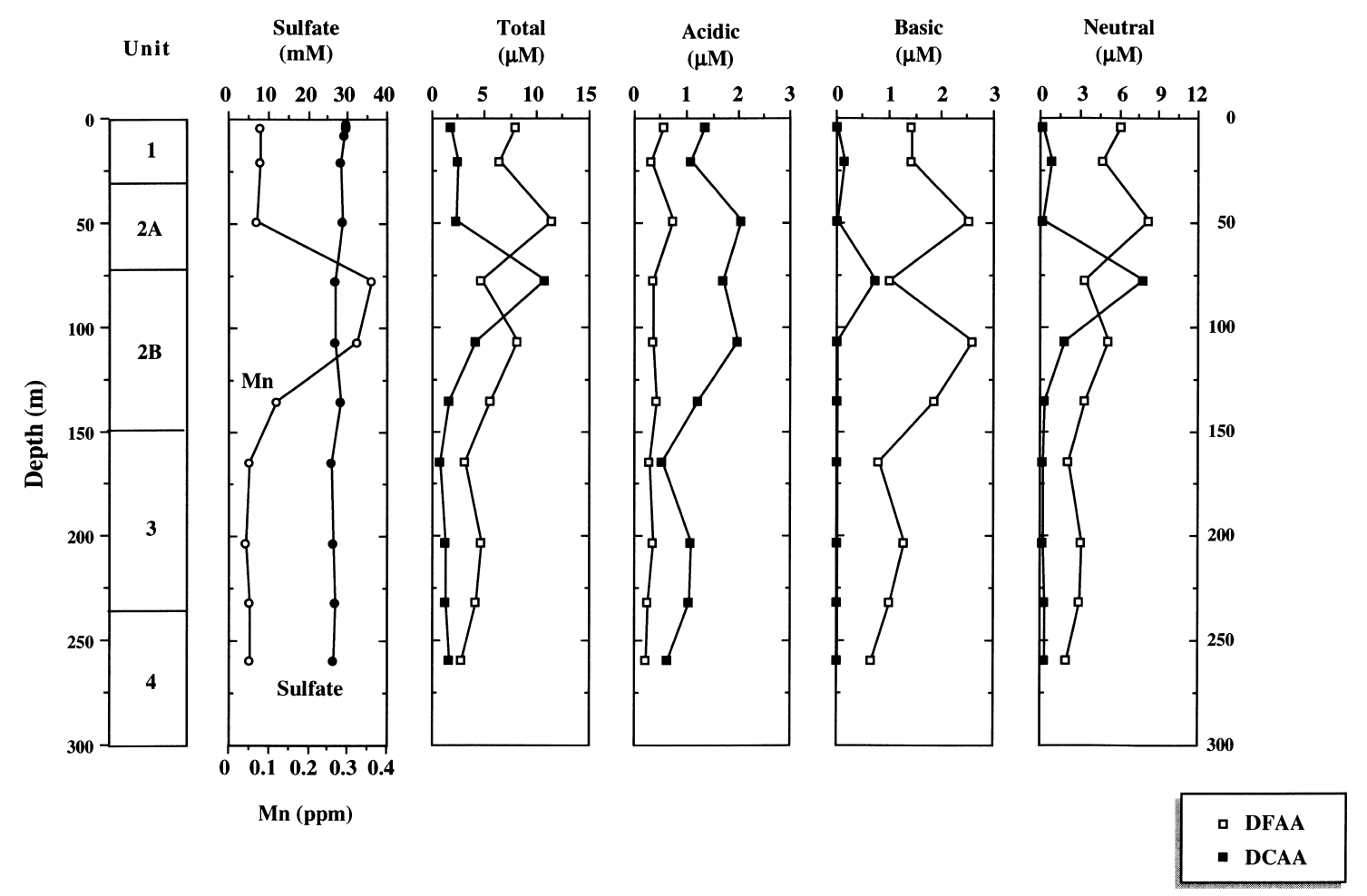

Fig. 2. Vertical distribution of the concentrations of total, acidic, basic and neutral amino acids of DCAA (solid square) and DFAA (open square) in interstitial waters from Site 689. Also dissolved Mn and sulfate are plotted together.

and then decreased to $3.1 \mathrm{mmol} \mathrm{L}-1$ at the bottom. The manganese concentration decreased from the surface to approximately $50 \mathrm{~m}$ and then increased towards the bottom (Fig. 3) (Barker et al., 1988).

\section{RESULTS}

The concentrations of the DCAA and DFAA in the interstitial waters from ODP Sites 689 and 690 are given in Tables 1 and 2 and plotted versus subbottom depth in Figs 2 and 3. The mean compositions of the DCAA and DFAA are presented in Fig. 4.

\section{Site 689}

The DCAA values ranged between 0.66 and $10.77 \mu \mathrm{mol} \mathrm{L}^{-1}$, averaging $2.74 \mu \mathrm{mol} \mathrm{L}{ }^{-1}$. Acidic amino acids were the most abundant fraction (average $1.25 \mu \mathrm{mol} \mathrm{L}^{-1}$ ) of the amino acids and ac- counted for $46 \mathrm{~mol} \%$ of the DCAA. The second most abundant fraction was the neutral amino acids with a mean value $1.16 \mu \mathrm{mol} \mathrm{L}^{-1}$, which constituted $42 \mathrm{~mol} \%$ of the DCAA. The basic amino acid fraction was $0.09 \mu \mathrm{mol} \mathrm{L} \mathrm{L}^{-1}$ on average, which accounted for $3 \mathrm{~mol} \%$ of the DCAA. The aromatic fraction was a minor component with the mean value $0.18 \mu \mathrm{mol} \mathrm{L}{ }^{-1}$. Relatively high concentration values of DCAA were found at $80 \mathrm{mbsf}$. Glutamic acid was the most abundant amino acid residue with serine, glycine and valine next (Fig. 2). $\beta$-amino butyric acid, nonprotein amino acids, constituted about 1 mol\% of the DCAA (Table 1).

The total DFAA values ranged from 2.73 to $11.36 \mu \mathrm{mol} \mathrm{L}{ }^{-1}$, averaging $5.87 \mu \mathrm{mol} \mathrm{L}{ }^{-1}$. Mean values of the acidic, basic and neutral amino acids were $0.38,1.45$ and $4.05 \mu \mathrm{mol} \mathrm{L}{ }^{-1}$, respectively. The relative abundances of the acidic, basic and neutral amino acids averaged 6, 25 and 69 


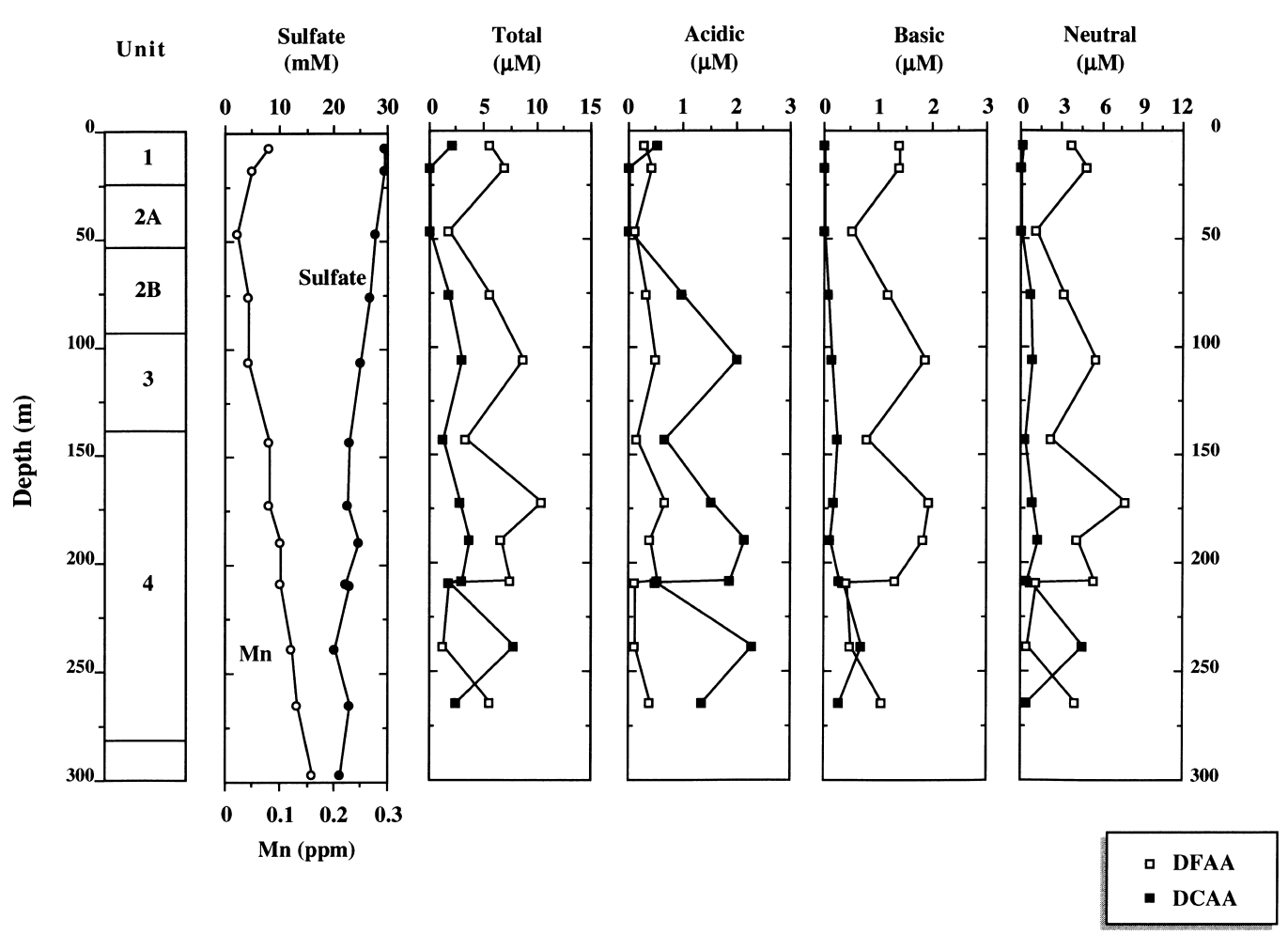

Fig. 3. Vertical distribution of the concentrations of total, acidic, basic and neutral amino acids of DCAA (solid square) and DFAA (open square) in interstitial waters from Site 690. Also dissolved Mn and sulfate are plotted together.

mol\%, respectively. Serine, ornithine and glycine were major amino acids of the DFAA. The DFAA composition showed no clear trend with depth (Fig. 2).

\section{Site 690}

The DCAA values ranged from zero to 7.78 $\mu \mathrm{mol} \mathrm{L}{ }^{-1}$, averaging $2.41 \mu \mathrm{mol} \mathrm{L}{ }^{-1}$. In Fig. 3, the DCAA showed a minimum around 20-50 mbsf, which rather corresponded to a minimum observed in Mn profile. Glutamic acid made up $40 \mathrm{~mol} \%$ of the DCAA. The mean values of the acidic, basic, neutral and aromatic amino acids are 1.15, 0.19, 0.82 and $0.16 \mu \mathrm{mol} \mathrm{L}{ }^{-1}$, respectively. The mean relative abundances of the acidic, basic, neutral and aromatic amino acids were 48, 8, 34 and 7 mol\%, respectively.

The total DFAA values ranged from 1.14 to $10.36 \mu \mathrm{mol} \mathrm{L}{ }^{-1}$, averaging $5.37 \mu \mathrm{mol} \mathrm{L}{ }^{-1}$. The mean values of acidic, basic, neutral and aromatic amino acid fractions were $0.32,1.18,3.62$ and 0.25 $\mu$ mol L ${ }^{-1}$, respectively. The mean relative abundances of the acidic, basic, neutral and aromatic amino acids were $6,22,67$ and $5 \mathrm{~mol} \%$, respectively.

\section{DISCUSSION}

General characteristics of DCAA in interstitial waters

Amino acids are present in free and combined states in the interstitial waters from Sites 689 and 690 (Figs. 2 and 3). The total concentrations of DCAA and DFAA values were on average 2.74 and $5.87 \mu \mathrm{mol} \mathrm{L}^{-1}$ at Site 689 and 2.41 and 5.37 $\mu$ mol L ${ }^{-1}$ at Site 690 , respectively. The results showed a predominance of DFAA over DCAA present in interstitial waters at ODP Sites 689 and 


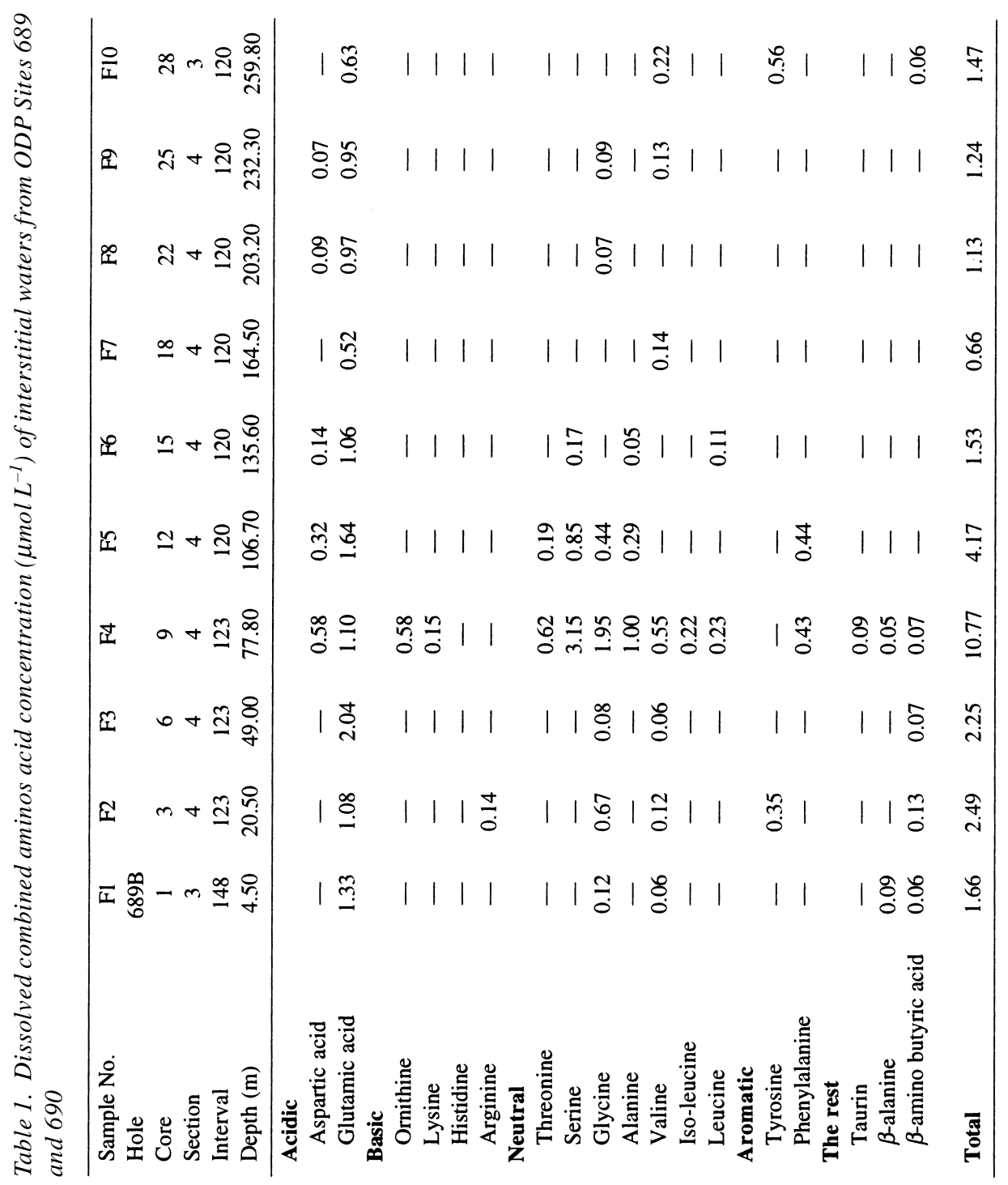




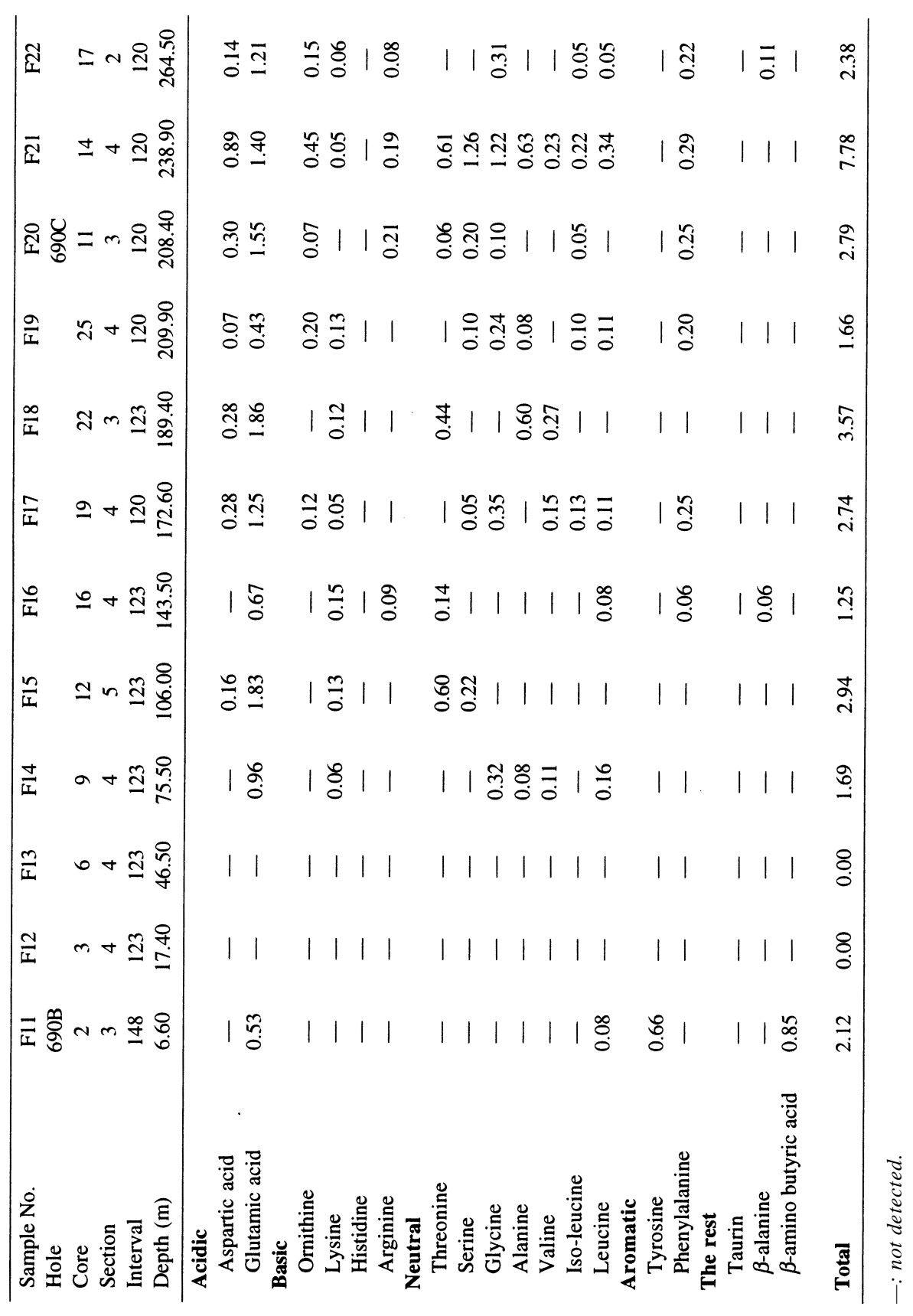




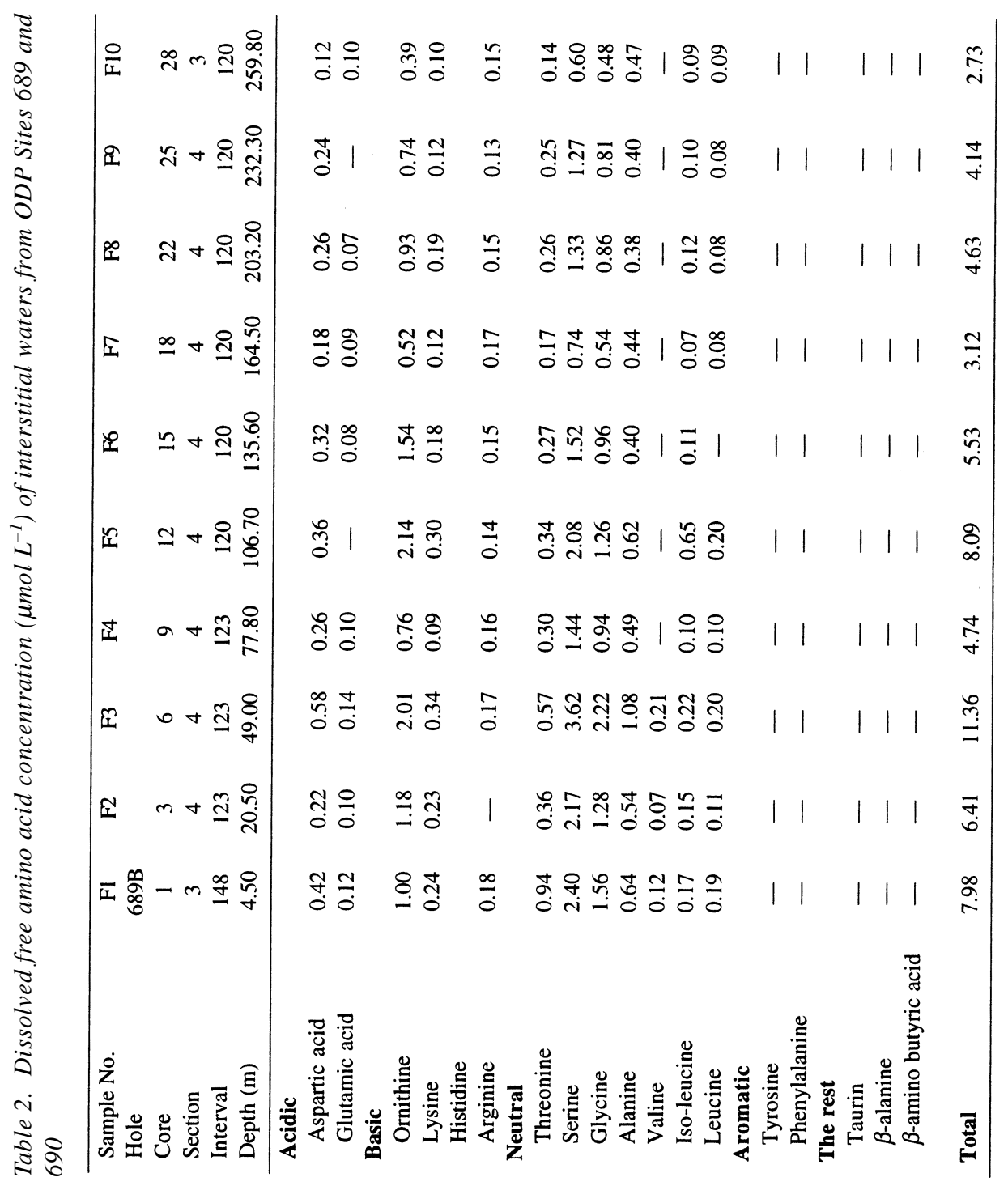




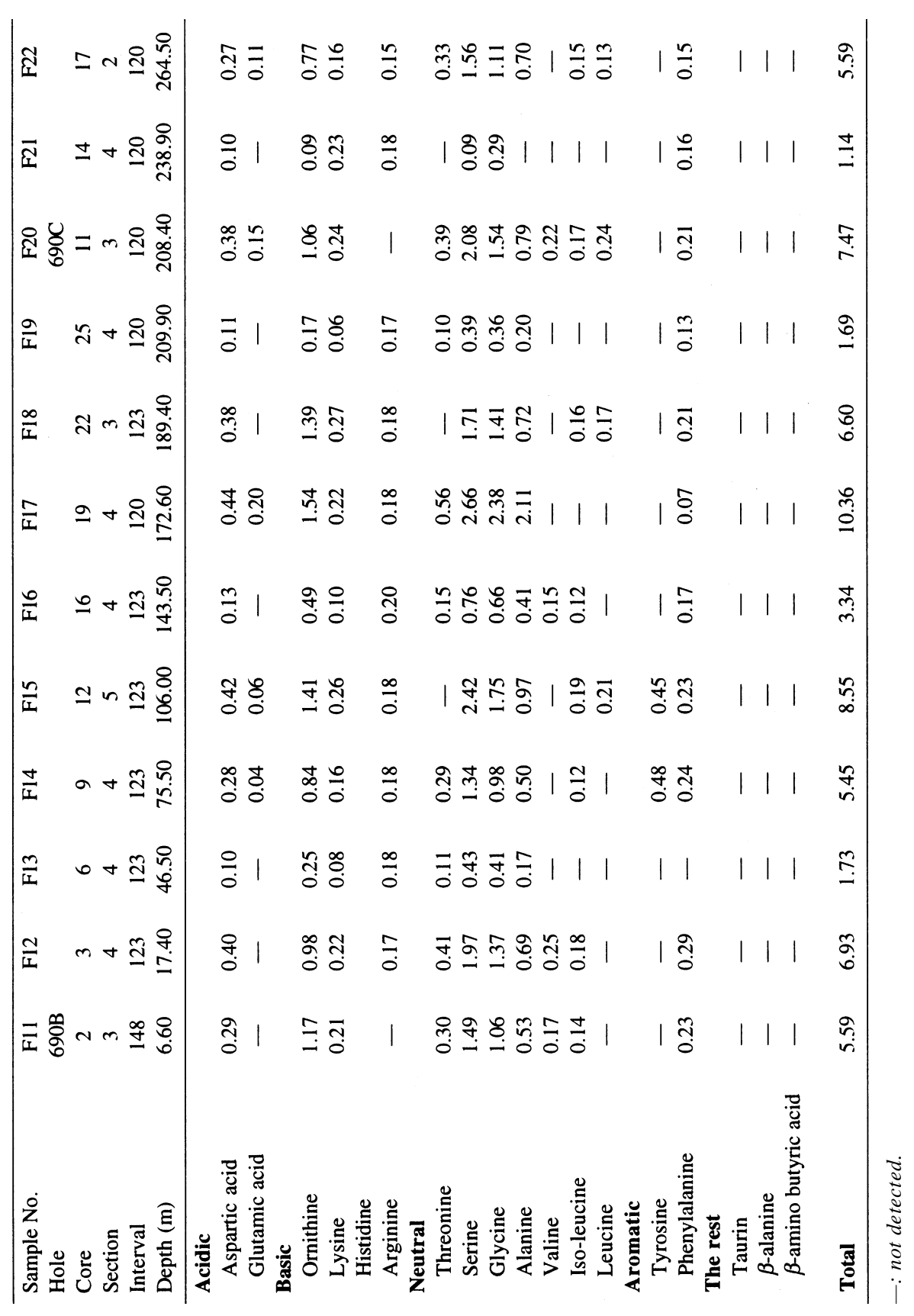




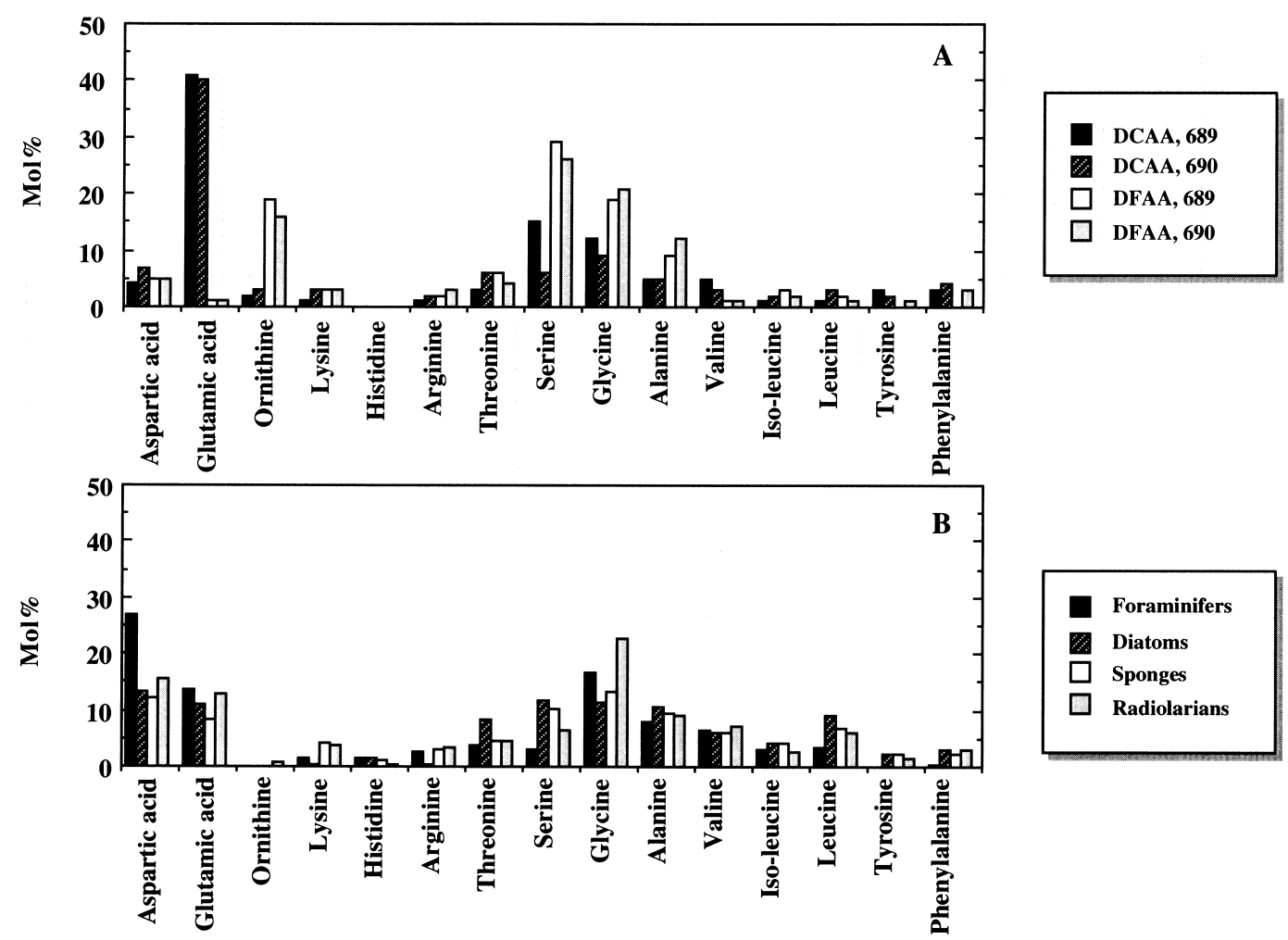

Fig. 4. (A) Mean relative abundances of dissolved combined amino acids (DCAA) and dissolved free amino acids (DFAA) in interstitial waters from Sites 689 and 690. (B) Relative abundances of amino acids in foraminifers (Peake et al., 1972), diatoms, sponges (Degens, 1970) and radiolarians (King, 1974).

690, which was against previous results from interstitial water and seawater studies (Lee and Bada, 1975; Kawahata and Ishizuka, 1989, 1992, 1993). Kawahata and Ishizuka $(1989,1993)$ found greater concentrations of the total DCAA (average, $5.1 \mu \mathrm{mol} \mathrm{L}^{-1}$ ) than the total DFAA (average, $3.2 \mu \mathrm{mol} \mathrm{L} \mathrm{L}^{-1}$ ) in the interstitial water from biogenic carbonate and silica-rich sediments from the Panama Basin. Similar results were obtained from interstitial waters from Sites 790 and 791 lying on a backarc graben west of the active Izu-Bonin volcanoes (Kawahata and Ishizuka, 1992). The total DCAA and the total DFAA values were on average 10.36 and $3.81 \mu \mathrm{mol} \mathrm{L}^{-1}$, respectively. Lee and Bada (1975) found that there is about ten times more DCAA than DFAA in seawater. The DFAA from open ocean water has larger percentages of alanine, aspartic acid and glutamic acid than the DCAA. Glycine, aspartic acid, alanine and serine make up about $80 \%$ of the THAA (Hubberten et al., 1994). One possible explanation for the higher DFAA at Sites 689 and 690 is reduced microbiological activity because small decrease in sulfate in interstitial waters results from low organic carbon content. It is consistent with low DOC concentrations at Sites 689 and 690 (Egeberg and Abdullah, 1990).

Smear slide observations indicated that the major constituents of the sediments from Sites 689 and 690 were biogenic material. Siliceous plankton including diatoms, radiolarians and silicoflagellates usually constituted more than $90 \%$ of the sediments in Unit 1 and middle of Unit 2 of Site 689 and in Unit 1 and middle of Unit 2A of Site 690. In the other units, calcareous nannofossils and foraminifers were the most important constituents, often making up more than $95 \%$. They eliminated the possibility of a major 

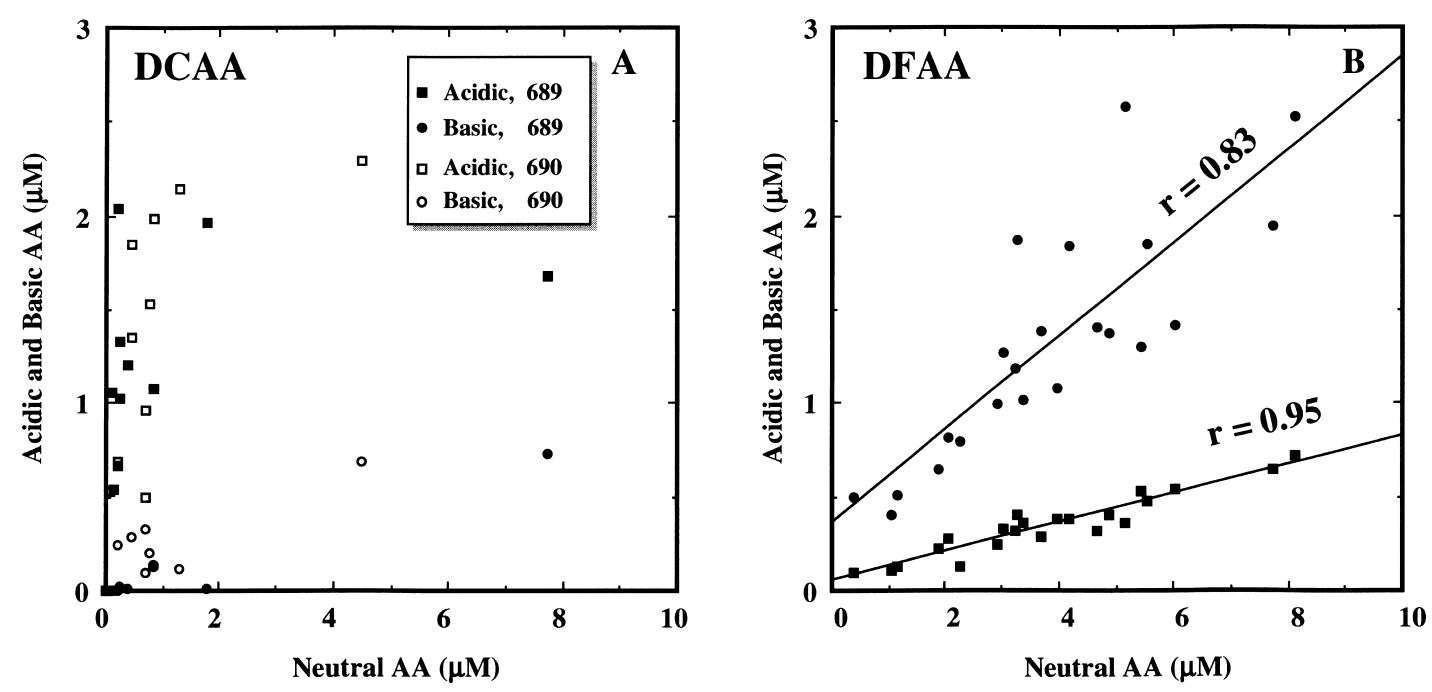

Fig. 5. (A) Acidic (square) and basic (circle) amino acids versus neutral amino acids of DCAA in interstitial waters from Sites 689 (solid) and 690 (open). (B) Acidic (square) and basic (circle) amino acids versus neutral amino acids of DFAA in interstitial waters from Sites 689 (solid) and 690 (open).

contribution of land-derived amino acids. Therefore, the DCAA in the interstitial waters probably originated from those of calcareous biogenic debris, with less amounts of siliceous debris.

One of the important characteristics of the relationship between amino acids of the source material and DCAA was enrichment in glutamic acid and depletion in aspartic acid and alanine (Fig. 4). Glutamic acid constituted as much as $41 \%$ of the total DCAA and was often one of the major constituents in interstitial waters because it is one of relatively stable amino acids (Garder and Hanson, 1979; Jørgensen et al., 1981; Burdige and Martens, 1984; Jørgensen, 1984; Henrichs et al., 1984; Henrichs and Farrington, 1987). In addition, Gardner and Hanson (1979) suggested that bacteria may produce relatively high levels of glutamic acid in interstitial waters.

General characteristics of dissolved free amino acids in interstitial waters

Although the acidic and basic amino acid fractions poorly correlated with the neutral amino acid fraction in the case of DCAA (Fig. 5A), they correlated positively in the case of DFAA (Fig. 5B). The correlation coefficient between the acidic and neutral fractions in the DFAA was 0.95 with the acidic/neutral molar ratio 0.091 (Fig. 5B). The correlation coefficient between the basic and neutral fractions was 0.83 with the basic/neutral molar ratio 0.34 (Fig. 5B). In spite of the high fluctuation of the DFAA concentration, the relative abundance of the individual amino acid fraction was fairly uniform throughout the two holes.

The adsorption or reaction of the amino acids in the interstitial waters with biogenic carbonates would be responsible for the lower relative abundance of the acidic fraction of DFAA than DCAA (Kawahata and Ishizuka, 1989). Especially glutamic acid constituted $41 \%$ of the total DCAA while it accounted for only $1 \%$ of the total DFAA.

Ornithine is an important nonprotein amino acid although it is absent from the foraminifer, diatom and sponge tests (Degens, 1970) and is much depleted in marine particulate mater (Ittekkot et al., 1984a). The mean relative abundance of ornithine in the DFAA from Sites 689 and 690 was about 19 and 16 mol\%, respectively. Ornithine is a decomposed product of arginine. The relative abundance of arginine in the DCAA and DFAA of Sites 689 and 690 was much less than that of biogenic debris, which supported the 
hypothesis that ornithine can be produced from arginine during early diagenesis. The molar ratio of ornithine to the other basic amino acids (lysine, histidine and arginine) was approximately 3 in the DFAA. The basic amino acid fraction was less stable than the acidic fraction in the free state (Abelson and Hare, 1971). In adsorption experiments of the amino acids in distilled water, basic (positively charged) amino acids are strongly adsorbed (40-80\% removal) and neutral (uncharged) amino acids are taken up appreciably (10-15\%) by montmorillonite (Hedges and Hare, 1987). Montmorillonite is common throughout the cores from Sites 689 and 690 in spite of its relatively small amount. Thus, the basic amino acid fraction tends to be decomposed in the interstitial waters and/or incorporated into the lattice of clay minerals (Stevenson and Cheng, 1970), which would result in a decrease in the relative abundance of the basic amino acid fraction.

\section{Relationship between DOC and total dissolved} amino acids in interstitial waters

Only a few studies have been carried out for DOC in interstitial waters of marine sediments buried deeper than $40 \mathrm{mbsf}$. Michaelis et al. (1982) reported DOC concentrations between 31 and 204 $\mathrm{mgC} \mathrm{L}^{-1}$ at ODP Sites 474 and 479 . No systematic depth trends were observed in this cases. Ishizuka et al. (1986b) reported DOC concentrations between 23 and $225 \mathrm{mgC} \mathrm{L}^{-1}$ at ODP Sites 618, 619 and 623 on the Mississippi Fan and Orcha and Pigmy Basins. On the other hand, DOC concentrations at Sites 689 and 690 were one to two orders of magnitude lower than those at above sites (1.82-6.91 $\mathrm{mgC} \mathrm{L}^{-1}$ ). Egeberg and Abdullah (1990) ascribed the low DOC concentration to significantly lower concentrations of sedimentary organic material deposited under low sedimentation rate. Mean organic carbon contents at Sites 689 and 690 were 0.11 and 0.15 , respectively, which was comparable to those observed in oligotrophic ocean in the western Pacific (Kawahata, 1999). The high rates of sedimentation and the high concentrations of sedimentary organic carbon lead to extensive sulfate reduction at Sites 473 and 479 (Gieskes et al., 1982) and at Sites 618 and 619 (Ishizuka et al., 1986a).

No systematic trends were found between the amino acid carbon and the DOC. The ratios of amino acid carbon to DOC concentrations ranged from 0.05 to 0.28 . Since DFAA was a major fraction of THAA, low molecular weight (LMW, molecular weight less than 1000) fractions were small contributor for the DOC. Previous studies of coastal (Krom and Sholkovitz, 1977) and hemipelagic sediments (Michaelis et al., 1982; Ishizuka et al., 1986b) have demonstrated that the bulk of DOC in marine interstitial waters is made up of complex high molecular weight (HMW, molecular weight greater than 1000) fractions. Krom and Sholkovitz (1977) argued that the HMW compounds are formed by condensation of LMW compounds released during biological degradation of sedimentary organic carbon. Harvey et al. (1983) showed that the condensation of polyunsaturated lipids to a humic compound involves oxidative cross-linking. The amount of DOC in interstitial waters may be considered to reflect the balance between rate of degradation, generation and rate of polymerization.

Earlier works on DOC in interstitial waters found that the most important factor governing the level of interstitial water DOC is the redox conditions of the subsurface environment (Krom and Sholkovitz, 1977). Dissolved manganese is the most redox-sensitive element measured in this study. Figure 2 showed that subsurface maximum of dissolved manganese occurred between 50 and $150 \mathrm{mbsf}$ at Site 689 , and the redox conditions at this depth were sufficiently reducing to stabilize manganese as $\mathrm{Mn}$ (II). High value and relatively high value of the DCAA were observed around 75 and 110 mbsf, respectively. Figure 3 showed that manganese concentration decreased in the 50 $m$ thick surface sediments and then increased with depth at Site 690 . The DCAA had a minimum between 25 and 50 mbsf. If we take the reducing conditions into consideration, it is reasonable to assume that the sulfate profile reflects an ongoing sulfate reduction. At both sites the fairly positive correlation between dissolved manganese 
concentration and total DCAA in interstitial waters suggested that microbial activity plays a significant role in regulating the concentration of DCAA. Poorly correlation between dissolved manganese concentration and total DFAA in interstitial waters at Site 690 might be related to the short residence time (a day or less) of DFAA pool due to the activity of microorganisms (Christensen and Blackburn, 1980; Fuhrman, 1990).

\section{SUMMARY AND CONCLUSIONS}

1. The DFAA was predominant over DCAA in the interstitial waters at ODP Sites 689 and 690, which contradicted previous results from interstitial water and seawater studies. The DCAA in interstitial waters probably originated from calcareous biogenic debris with less amounts of siliceous debris. One of the important characteristics of the relationship between the amino acids of the source material and DCAA was enrichment of glutamic acid and depletion of aspartic acid and alanine in DCAA.

2. The acidic and basic amino acid fractions correlated positively with the neutral amino acid fractions in DFAA in interstitial waters. Glutamic acid constituted $41 \%$ of the total DCAA while it accounted for only $1 \%$ of the total DFAA. It is due to the adsorption or reaction of the amino acids in the interstitial waters with biogenic carbonates. Ornithine, an important nonprotein amino acid, in the DFAA constituted approximately 17 mol\%. It is probably produced during early diagenesis.

3. The ratio of amino acid carbon to DOC concentration ranged from 0.05 to 0.28 , which supported the idea that high molecular weight organic matter is a major contributor for DOM in interstitial waters.

4. Dissolved manganese was the most redoxsensitive element measured in this study. At both sites the positive correlation between dissolved manganese concentration and the total DCAA in interstitial waters suggested that the redox condition plays a significant role in determining the DCAA concentrations.
Acknowledgments - The authors would like to express their appreciation to Prof. Koike, I. (University of Tokyo) for valuable suggestions. They also express their appreciation to Dr. Matsumoto, G. (Otsuma Women's University) and Dr. Harada, N. (JAMSTEC) for reviewing the manuscript and giving comments to improve the manuscript. Figures were drawn by Ms. K. Nagayoshi. This study was supported by "Global carbon cycle and related mapping based upon satellite imagery" funded by Science and Technology Agency and "Study on paleoceanography" funded by Geological Survey of Japan.

\section{REFERENCES}

Abelson, P. H. and Hare, P. E. (1971) Reaction of amino acids with natural and artificial humus and kerogens. Carnegie Inst. Washington, D.C., Yearb. 69, 327-334.

Azam, F., Fenchel, T., Field, J. G., Gray, J. S., MeyerReil, L. A. and Thingstad, F. (1983) The ecological role of watercolumn microbes in the sea. Mar. Ecol. Pror. Ser. 10, 257-263.

Barker, P. F., Kenett, J. P. et al. (1988) Proc. ODP, Initial Reports, 113 (Barker, P. F., Kennett, J. P. et al., eds.), 1-785, College Station, TX (Ocean Drilling Program), U.S.A.

Bauer, J. E., Williams, P. M. and Druffel, E. R. M. (1992) ${ }^{14} \mathrm{C}$ activity of dissolved organic carbon fractions in the north-central Pacific and Sargasso Sea. Nature 357, 667-670.

Burdige, D. and Martens, C. D. (1984) Amino acid cycling in an organic-rich marine sediments. EOS $\mathbf{6 5}$, 960.

Christensen, D. and Blackburn, T. H. (1980) Turnover of tracer $\left({ }^{14} \mathrm{C},{ }^{3} \mathrm{H}\right.$ labelled $)$ alanine in shore marine sediments. Mar. Biol. 58, 97-103.

Collins, M. J., Muyzer, G., Westbroek, P., Curry, G. B., Sandberg, P. A., Xu, S. J., Quinn, R. and MacKinnon, D. (1991) Preservation of fossil biopolymeric structures: conclusive immunological evidence. Geochim. Cosmochim. Acta 55, 22532257.

Collins, M. J., Westbroek, P., Muyzer, G. and Leeuw, J. W. (1992) Experimental evidence for condensation reactions between sugars and proteins in carbonate skeletons. Geochim. Cosmochim. Acta 56, 15391544.

Degens, E. T. (1970) Molecular nature of nitrogenous compounds in seawater and recent marine sediments. Inst. Mar. Science (Proceedings for Symposium on Organic Matter in Natural Waters), Occas. Publ. (Hood, D. W., ed.), 1, 77-106, Alaska, U.S.A. 
Egeberg, P. K. and Abdullah, M. I. (1990) The diagenetic factors controlling the dissolved organic carbon (DOC) in pore water from deep sea sediments (ODP Leg 113, Weddell Sea). Proc. ODP, Sci. Results, 113 (Barker, P. F., Kennett, J. P. et al., eds.), 169-177, College Station, TX (Ocean Drilling Program), U.S.A.

Egeberg, P. K., Smalley, P. C. and Aagaard, P. (1990) Strontium isotope geochemistry of Leg 113 interstitial waters and carbonates. Proc. ODP, Sci. Results, 113 (Barker, P. F., Kennett, J. P. et al., eds.), 147157, College Station, TX (Ocean Drilling Program), U.S.A.

Fuhrman, J. (1990) Dissolved free amino acid cycling in an estuarine outflow plume. Mar. Ecol. Progr. Ser. 66, 197-203.

Garder W. S. and Hanson, R. B. (1979) Dissolved free amino acids in interstitial water of Georgia salt marsh soils. Estuaries 2, 113-118.

Gieskes, J. M., Elderfield, H., Lawrance, R., Johnson, J., Meyers, B. and Campbell, A. (1982) Geochemistry of interstitial waters and sediments, Leg 64, Gulf of California. Init. Repts. DSDP, 64 (Curray, J. R. and Moore, D. G., eds.), 675-694, U.S. Govt. Printing Office, Washington, D.C., U.S.A.

Haake, B., Ittekkot, V., Ramaswamy, V., Nair, R. R. and Honjo, S. (1992) Fluxes of amino acids and hexosamines to the deep Arabian Sea. Mar. Chem. 40, 291-314.

Harvey, G. R., Boran, D. B., Chesal, L. A. and Tokar, J. M. (1983) The structure of marine fulvic and humic acids. Mar. Chem. 2, 119-132.

Hedges, J. I. (1988) Polymerization of humic substances in natural environments. Humic Substances and Their Role in the Environment (Frimmel, F. H. and Christman R. F., eds.), 45-58, Wiley, New York, U.S.A.

Hedges, J. I. and Hare, P. E. (1987) Amino acid adsorption by clay minerals in distilled water. Geochim. Cosmochim. Acta 51, 255-259.

Henrichs, S. M. and Farrington, J. W. (1979) Amino acids in interstitial waters of marine sediments. $\mathrm{Na}$ ture 279, 319-322.

Henrichs, S. M. and Farrington, J. W. (1987) Early diagenesis of amino acids and organic matter in two coastal marine sediments. Geochim. Cosmochim. Acta 51, 1-15.

Henrichs, S. M., Farrington, J. W. and Lee, C. (1984) Peru upwelling region sediments near $15^{\circ} \mathrm{S}$. 2. Dissolved free and total hydrolyzable amino acid. Limnol. Oceanogr. 29, 20-34.

Hubberten, U., Lara, R. J. and Kattner, G. (1994) Amino acid composition of seawater and dissolved humic substances in the Greenland Sea. Mar. Chem. 45,
121-128.

Ishizuka, T., Kawahata, H. and Aoki, S. (1986a) Interstitial water geochemistry and clay mineralogy of the Mississippi fan and Orca and Pigmy basins, Deep Sea Drilling Project Leg 96. Init. Repts. DSDP, 96 (Bouma, A. H., Coleman, J. M. et al., eds.), 711728, U.S. Govt. Printing Office, Washington, D.C., U.S.A.

Ishizuka, T., Ittekkot, V., Degens, E. T. and Kawahata, H. (1986b) Preliminary data on dissolved organic carbon and sugar in interstitial water from the Mississippi Fan and Orca and Pigmy Basins, Deep Sea Drilling Project Leg 96. Init. Repts. DSDP, 96 (Bouma, A. H., Coleman, J. M. et al., eds.), 729732, U.S. Govt. Printing Office, Washington, D.C., U.S.A.

Ishizuka, T., Nozaki, Y. and Shimooka, K. (1988) Amino acids in the interstitial waters of ESOPE long cores from two North Atlantic abyssal plains. Geochem. J. 22, 1-8.

Ittekkot V., Deuser, W. G. and Degens, E. T. (1984a) Seasonality in the fluxes of sugars, amino acids, and amino sugars to the deep ocean: Sargasso Sea. DeepSea Res. 31, 1057-1069.

Ittekkot V., Degens, E. T. and Honjo, S. (1984b) Seasonality in the fluxes of sugars, amino acids, and amino sugars to the deep ocean: Panama Basin. DeepSea Res. 31, 1071-1083.

Jørgensen, N. O. G. (1984) Microbial activity in the water-sediment interface: assimilation and production of dissolved free amino acids. Oceanis 10, 365377.

Jørgensen, N. O. G., Lindroth, P. and Mopper, K. (1981) Extraction and distribution of free amino acids and ammonium in sediments and overlying sea waters from the Limfjord, Denmark. Oceanol. Acta 4, 465474.

Kawahata, H. (1999) Fluctuations in the ocean environment within the Western Pacific Warm Pool during Late Pleistocene. Paleoceanography 14, 639652.

Kawahata, H. and Ishizuka, T. (1989) Organic property of sediments and amino acids in interstitial waters from the flank of Costa Rica Rift, Galapagos Spreading Center (ODP Site 677 and 678). Proc. ODP, Sci. Results, 111 (Becker, K., Sakai, H. et al., eds.), 215-225, College Station, TX (Ocean Drilling Program), U.S.A.

Kawahata, H. and Ishizuka, T. (1992) Amino acids in the interstitial waters from ODP Sites 790 and 791 in the Izu-Bonin Island Arc. Proc. ODP, Sci. Results, 126 (Taylor, B., Fujioka, K. et al., eds.), 531-540, College Station, TX (Ocean Drilling Program), U.S.A. 
Kawahata, H. and Ishizuka, T. (1993) Amino acids in the sediments and interstitial waters from ODP Holes 677B and 678B in the Panama Basin. Oceanol. Acta 16, 373-379.

Kawahata, H., Ishizuka, T. and Nagao, T. (1990) Amino acids in interstitial waters from the ODP Site 695 in the Weddell Sea, Antarctic Ocean. Proc. ODP, Sci. Results, 113 (Barker, P. F., Kennett, J. P. et al., eds.), 179-187, College Station, TX (Ocean Drilling Program), U.S.A.

King, J. J. (1974) Preserved amino acids from silicified protein in fossil radiolarians. Nature 252, 690-692.

Krom, M. D. and Sholkovitz, E. R. (1977) Nature and reaction of dissolved organic matter in the interstitial waters of marine sediments. Geochim. Cosmochim. Acta 41, 1565-1573.

Lee, C. and Bada, J. L. (1975) Amino acids in equatorial Pacific Ocean water. Earth Planet Sci. Lett. 26, 61-68.

Maita, Y., Montani, S. and Ishii, J. (1982) Early diagenesis of amino acids in Okhotsk Sea sediments. Deep-Sea Res. 29, 485-498.
Michaelis, W., Mycke, B., Vogt, J., Schuetze, G. and Degens, E. T. (1982) Organic geochemistry of interstitial waters, Sites 474 and 479, Leg 64. Init. Repts. DSDP, 64 (Curray, J. R., Moore, D. G. et al., eds.), 933-937, U.S. Govt. Printing Office, Washington, D.C., U.S.A.

Peake, E. P., Baker, B. L. and Hodgson, G. W. (1972) Hydrogeochemistry of the surface waters of the Mackenzie River drainage basin, Canada. II. The contribution of amino acids, hydrocarbons and chlorine to the Beaufort Sea by the Mackenzie River system. Geochim. Cosmochim. Acta 36, 867-883.

Stevenson, F. J. and Cheng, C.-N. (1970) Amino acids in sediments: recovery by acid hydrolysis and quantitative estimation by a colorimetric procedure. Geochim. Cosmochim. Acta 34, 77-88.

Whelan, J. K. (1977) Amino acids in surface sediment core of the Atlantic abyssal plain. Geochim. Cosmochim. Acta 41, 803-810.

Williams, P. M. and Druffel, E. M. (1987) Radiocarbon in dissolved organic matter in the central north Pacific Ocean. Nature 330, 246-248. 